IZA DP No. 5737

Economies of Scale in the Tunisian Industries

Almas Heshmati

Ilham Haouas

May 2011 


\title{
Economies of Scale in the Tunisian Industries
}

\author{
Almas Heshmati \\ Korea University \\ and IZA \\ Ilham Haouas \\ Abu Dhabi University

\section{Discussion Paper No. 5737} \\ May 2011 \\ IZA \\ P.O. Box 7240 \\ 53072 Bonn \\ Germany \\ Phone: +49-228-3894-0 \\ Fax: +49-228-3894-180 \\ E-mail: iza@iza.org
}

Any opinions expressed here are those of the author(s) and not those of IZA. Research published in this series may include views on policy, but the institute itself takes no institutional policy positions.

The Institute for the Study of Labor (IZA) in Bonn is a local and virtual international research center and a place of communication between science, politics and business. IZA is an independent nonprofit organization supported by Deutsche Post Foundation. The center is associated with the University of Bonn and offers a stimulating research environment through its international network, workshops and conferences, data service, project support, research visits and doctoral program. IZA engages in (i) original and internationally competitive research in all fields of labor economics, (ii) development of policy concepts, and (iii) dissemination of research results and concepts to the interested public.

IZA Discussion Papers often represent preliminary work and are circulated to encourage discussion. Citation of such a paper should account for its provisional character. A revised version may be available directly from the author. 
IZA Discussion Paper No. 5737

May 2011

\section{ABSTRACT}

\section{Economies of Scale in the Tunisian Industries}

To date, empirical investigations of trade liberalization under the conditions of increasing returns to scale (IRS) and imperfect competition (IC) have either assumed or imposed the market and productive structures necessary for such a model. However, of the recent IRS/IC models used to simulate the effects of trade liberalization none have empirically tested for the presence of increasing return to scale prior to the analysis. With Tunisian data (1971-2004) and rigorous test procedures, we investigate evidence of IRS at the industry level. Using an econometric approach based on the estimation of the translog cost function and its associated cost share equations, we identify the sectors characterized by increasing returns to scale. Analysis of the results shows that specification of the model is sensitive to inclusion of time trend representing technology. The model accounting for technology did not fit the data well for most sectors. The estimation results without time trend interactions are different. Here most of the sectors show signs of increasing returns to scale.

JEL Classification: $\quad$ C32, C52, D24, F12, L00

Keywords: economies of scale, trade liberalization, new trade theory, Tunisian industries, cost functions

Corresponding author:

Almas Heshmati

Department of Food and Resource Economics

College of Life Sciences and Biotechnology

Korea University

East Building, Room \#217

Anam-dong Seongbuk-gu

Seoul 136-701

Korea

E-mail: heshmati@korea.ac.kr 


\section{Introduction}

In most recent decades, a large number of countries have modified their trade politics. They have moved from an import-oriented to export-oriented policies. In most cases, the consequences of these changes are the reduction or the elimination of the restrictions imposed on the international trade relations. The elimination of these restrictive measures is generally destined to improve the performance of the economy. Indeed, some governments try to increase their exports, whereas others try to develop the local industry in order to attract foreign direct investment. Thus, certain governments in developing countries try to introduce trade policy changes in an attempt to develop their manufacturing exports in order to increase their incomes.

Economists generally agree that for an overly protected less development country (LDC), trade liberalization is a sound policy to redress external imbalance and to correct an inefficient allocation of productive resources. To demonstrate the worthiness of this policy, researchers have constructed models to measure the gains to trade liberalization. In most instances, the net gains arising from such models were found to be quite small. This quandary prompted several models to question some of the fundamental assumptions underlying construction of such models, principal among which were perfect competition and constant returns to scale.

In these contexts, the literature within the "New Trade Theory" with increasing returns to scale and imperfectly competitive markets suggest that the gain to trade liberalization will be larger than those predicted by models where markets are perfectly competitive and characterized by constant returns to scale. The primary mechanisms responsible for this greater gains are a reduction in the number of firms in an industry (industry rationalization) and the decrease in domestic price and costs of production following liberalization (the pro-competitive effect). Assuming domestic import is imperfectly competitive, reducing tariff barriers tightness competition and forces domestic oligopolistic firms to lower price along their declining average cost curves. This lead to price and costs of production falls and output increases, while the number of firms in the oligopolistic industry declines. Gains occur due to lowered prices and cost of production, exit of inefficient producers from the industry and an improved allocation of resources. This literature is concentrated on modelling trade in an environment where production takes place under conditions of increasing returns to scale and where markets are imperfectly competitive. Krugman (1979), Dixit and Norman (1980) and Lancaster (1980) considered the implications of returns to scale for trade theory using as "little" market structure as possible, opting for monopolistic competition. As the literature developed, interest grew in imperfect competition for its own sake and accordingly, attention been focused on oligopolistic interaction.

To date, empirical investigations of trade liberalization under these conditions have either assumed or imposed the structures necessary for such a model. Of these recent IRS/IC models used to simulate the effects of trade liberalization (Harris, 1984; Guanasekera and Tyers, 1991; Devarajan and Rodrik, 1991; Hertel, 1991; Markusen and Venables, 1988) but none has tested empirically for the presence of increasing return to scale prior to the analysis. For the empirical analysis and illustration we use industry level data from Tunisia which is a country with comprehensive trade liberalization policy. 
The objective of this paper is to analyse Tunisian data to see if evidence of increasing returns to scale at the industry level can be found and to identify those sectors most likely their production structure to be characterized by increasing returns to scale. The information will be helpful to shed lights on the validity of assumptions underlying applications of the New Trade Theory and in preparation for the construction of a Computable General Equilibrium (CGE) model of trade liberalization.McDonough (1992) discusses the homothetic and non-homothetic scale economies in applied general equilibrium analysis.

The rest of the paper is structured as follows. The evolution of the activity of the Tunisian trade policy and industry is discussed in Section 2. Section 3 provides a brief description of some evidence cited by previous studies in the field. In Section 4, we present the research model, followed by the estimation procedure and data in Section 5 and 6. The empirical results are discussed in Section 7 and are compared with the previous findings. Section 8 concludes.

\section{Evolution of the Tunisian Trade Policies and Industries}

Four phases have marked the evolution and the development of the Tunisian industry. The first three phases (from 1960 to 1969,1970 to 1979 and 1980 to 1986) has allowed the development and the installation of the physical infrastructure and the launching of basic industries, such as the chemical, the food processing and the textile industries, characterized by a direct intervention of the government and a policy of protection of domestic market. These industries have shown positive growth due to a stable political climate, customs protections and the subvention given to the public companies. However, after the economic crisis between 1980 and 1986, and during the fourth phase numerous measures have been taken to liberalize the international trade (Boudhiaf, 2000). These include the Structural adjustment programme (1986), adherence to the General Agreement on Terms of Trade GATT (1989), adherence to the World Trade Organization WTO (1994), and signing of free-trade agreement with the European Union (1995).

The measures listed above liberalized the economy (liberalization of the imports, the prices, the investment, progressive reduction of the customs rates) and it affected the competitiveness of the companies, both on and outside the frontiers. The reforms introduced during this phase implied also the introduction of certain measures to accompany liberalization, such as reforms to support the institutions, the simplification of the tax reform, the code reform of the foreign trade, and the simplification of the politics to enhance incentive to investment. These aimed at continuation of the process of structural adjustment and privatization, i.e. the disengagement of the government with all corporations' activities in production or services.

\section{Some Previous Applications}

There are several studies which in one or another way have used empirical investigations of trade liberalization under the assumption of increasing returns to scale and imperfect competition. However, none of these studies has tested empirically for the presence of increasing return to scale. A few of these studies are reviewed below. 
Harris (1984), in his seminal study of Canadian trade liberalization, simply assumes that some sectors are characterized by increasing returns to scale while others are constant returns to scale. De Melo and Roland-Holst (1990) motivate their model assumptions for Korea based on evidence from price-cost margins found in an earlier study. The evidence showed that sectors with a low import share in total sales had higher price-cost margins, suggesting an imperfectly competitive structure, possibly the result of a production process where returns to scale are increasing. Gunasekera and Tyers (1991) also construct an imperfectly competitive trade model based on Korea. They cite secondary sources and discuss the "stylized facts" concerning the oligopolistic nature of Korean industry.

Devarajan and Rodrik (1991) construct an IRS/IC model for Cameroon but, due to data limitations, they are unable to provide any evidence other than an appeal to the idea that imperfect competition is probably more likely prevalent than perfect competition in a developing country context. List and Zhou (2007) is another study in which the authors use a general equilibrium model to explore the implications of firms' technology choices and the substitution of capital for labour for economic growth. In this model, increasing returns to scale arise from the fixed cost of production embodied in machines and it is internal to a firm.

\section{The Model}

\subsection{Returns to Scale Studied via the New Trade Theory Models}

The existing body of economic theory and empirical literature suggests four ways in which the case for increasing returns to scale might be studied.

\section{Returns to scale using production functions}

Ignoring the problems involved in specification and estimation of production functions, estimates of the coefficients of a production function can be used to calculate directly the returns to scale. A problem with this and the cost function approach is that the estimates from aggregate industry level data do not allow identification of disaggregate firm level returns to scale. Individual firms may be characterized by increasing returns to scale while the industry as a whole exhibits constant returns to scale. In the top down approach, i.e. from aggregate to disaggregate level, intermediate deliveries from inter-industry and intra-industry sources complicate the issue. In aggregate economy intra-industry cancels out but not the inter-industry component affecting return to scale in production functions.

\section{Returns to scale using intra-industry trade}

There is a need to explain the preponderance of intra-industry trade when previous studies predicted little or none (preferring instead inter-industry) led to the development of the "New Trade Theory". Significant intra-industry trade could be seen as indirect evidence for a "New Trade Theory" model having characteristics of imperfect competition and increasing returns to scale. A problem with this kind of approach is that the pattern of trade may be due to other factors not accounted for in either the theory or the empirical work. Although data for exports and imports are available, we choose not to rely on this information because evidence of intra-industry trade does not unequivocally prove the case of increasing returns to scale. Outsourcing and subcontracting to create cost saving opportunities, to share risk, to increase firms' specialization in areas with 
comparative advantage and to concentrate specialization are examples of intra-industry trade that are neglected in inter-industry studies, which overestimate the effect in bottom up models by double counting.

Returns to scale using market structure

The approach of market concentration ratios provide indirect evidence of imperfectly competitive behaviour, which may be the result of increasing returns to scale. This approach was used by Aw (1990), Gunasekera and Tyers (1991), Devarajan and Rodrik (1989) and Ethier (1982) in their work on imperfectly competitive trade models. A drawback of this approach is that the imperfect competition may be due to factors other than scale economies, e.g., government regulation, trade policy, etc.

Returns to scale using cost functions

Abstracting from the problems involved in estimating a cost function, a well estimated cost function provides direct evidence of returns to scale and the shape of the cost curves. In addition, the scale biased technological change, resulting from the impacts of technology on cost channelled through changes in the level of output, and contributions from its factor components can be identified and estimated.

\subsection{The Translog Cost Function}

Estimation of the cost function has some advantages over the production function estimation. First, estimation of the cost function, along with input share equations adds a first order condition for input usage that places cross-equation restrictions on the parameters and thereby improves the efficiency of the estimates. Second, in general, the cost function imposes fewer a priori assumptions on the substitution possibilities among the factors of production and it allows scale economies to vary with the level of output and allowing for size heterogeneity of scale economies. In keeping with a desire to impose few a priori assumptions on the technology, we opted for the translog cost function $^{1}$. The translogform allows scale economies to vary with the level of output and it can accommodate homothetic, homogeneous and unit elasticity of substitution forms within its general functional form structure.

The model used follows the one initiated in Christensen and Greene (1976) and modified and improved upon in later efforts. ${ }^{2}$ The general translog cost function for value-added with two inputs of capital and labour with input prices $\mathrm{P}_{\mathrm{i}}$ respectively, referred to as Basic Model is written as:

$$
\begin{aligned}
\ln T C=\alpha_{0} & +\alpha_{Y} \ln Y+1 / 2 \gamma_{Y Y}(\ln Y)^{2}+\sum_{i} \alpha_{i} \ln P_{i}+1 / 2 \sum_{i} \sum_{j} \gamma_{i j} \ln P_{i} \ln P_{j} \\
& +\sum_{i} \gamma_{Y i} \ln Y \ln P_{i}+\varepsilon
\end{aligned}
$$

\footnotetext{
${ }^{1}$ See Christensen, Jorgenson, and Lau (1973).

${ }^{2}$ See Caves and Christensen (1980), Caves, Christensen, and Swanson (1980 and 1981), Friedlander, Winston, and Wang (1983), Gupta and Taher (1984), Caves, Christensen and Tretheway (1984), Antle and Crissman (1988), and Kress (1994).
} 
Where $\gamma_{i j}=\gamma_{j i}$ assumes symmetry, TC is total cost, $Y$ is the value added, and subscripts $i$ and $j$ indicate inputs. For the reasons of simplification of the notations at this stage we ignore the time and industry subscripts.

Given the time-series nature of this dataset, the effect of technology on the cost structure of industries must be taken into account. One possible solution is merely to add time as an independent variable to the above equation. However, the literature on cost function estimation prefers treatment of the time trend $(Z)$ as an input and in order to capture its non-linearity and non-neutrality impacts interact time trend with the other prices and output explanatory terms. Thus, the cost function equation to be estimated, with time trend introduced explicitly, is referred to as the unrestricted model (Model I), and iswritten as:

$$
\begin{aligned}
\ln T C=\alpha_{0} & +\alpha_{Y} \ln Y+1 / 2 \gamma_{Y Y}(\ln Y)^{2}+\sum_{i} \alpha_{i} \ln P_{i}+1 / 2 \sum_{i} \sum_{j} \gamma_{i j} \ln P_{i} \ln P_{j} \\
& +\sum_{i} \gamma_{Y i} \ln Y \ln P_{i}+\alpha_{t} Z+1 / 2 \gamma_{t t} Z^{2}+\gamma_{t Y} Z \ln Y+\sum_{i} \gamma_{t i} Z \ln P_{i}+\varepsilon
\end{aligned}
$$

where $\mathrm{Z}$ indicates technology and often isrepresented by a time trend variable. In order to correspond to a well-behaved production function, a cost function must be homogeneous of degree one in input prices, i.e., for a fixed level of output the total cost must increase proportionally when all input prices increase proportionally. This implies the following relationships among the parameters of the model:

$$
\sum_{i} \alpha_{i}=1, \sum_{i} \gamma_{Y i}=0, \sum_{i} \gamma_{i j}=\sum_{j} \gamma_{i j}=\sum_{i} \sum_{j} \gamma_{i j}=0
$$

A convenient feature of the cost function approach is that the derived demands for the factors of production are computed by reference to Sheppard's lemma (Sheppard, 1953). A differentiation of the logarithmic cost function, with respect to the logarithm of factor prices, results in the cost share equations for the inputs. For instance, the capital and labour share equations are derived as:

$$
\begin{aligned}
& S_{K}=\partial \ln T C / \partial \ln P_{K}=\left(P_{K} K\right) / T C=\alpha_{K}+\sum_{j} \gamma_{i j} \ln P_{j}+\gamma_{Y K} \ln Y+\gamma_{t K} Z \\
& S_{L}=\partial \ln T C / \partial \ln P_{L}=\left(P_{L} L\right) / T C=\alpha_{L}+\sum_{j} \gamma_{i j} \ln P_{j}+\gamma_{Y L} \ln Y+\gamma_{t L} Z
\end{aligned}
$$

In similar way, and as in the literature related to the measurement of technical change and total factor productivity growth ${ }^{3}$, the rate of technical change is obtained by taking the derivative of the cost function with respect to time:

$$
S_{Z}=\partial \ln T C / \partial Z=\alpha_{t}+\alpha_{t t} Z+\sum_{i} \gamma_{t i} \ln P_{i}+\gamma_{Y t} \ln Y
$$

\footnotetext{
${ }^{3}$ For a survey of different parametric and no-parametric methods in estimation of rate of total factor productivity growth and its decomposition using manufacturing and services data see Heshmati (2003).
} 
It can further be decomposed into neutral $\left(\alpha_{t}+\alpha_{t t} Z\right)$, non-neutral $\left(\sum_{i} \gamma_{t i} \ln P_{i}\right)$, and scale augmenting $\left(\gamma_{Y t} \ln Y\right)$ components.The measure of scale economies is defined as the elasticity of total cost with respect to output. ${ }^{4}$ This elasticity is obtained by partial differentiation of the logged cost function with respect to the log of value-added and it represents the proportional increase in costs resulting from a proportional increase in the level of value-added. The elasticity is written as:

$$
S C A L E=\partial \ln T C / \partial \ln Y=\alpha_{Y}+\gamma_{Y Y} \ln Y+\sum_{i} \gamma_{Y i} \ln P_{i}+\gamma_{t Y} Z
$$

These results are suggesting increasing returns to scale when the above measure of scale economies is less than one; a value greater than one represents decreasing returns to scale, while a value equal to one suggest constant returns to scale. In other words, returns to scale is obtained as the inverse of the scale effect. Increasing returns to scale implies that cost increases proportionally less than output.

It is to be noted that the formula for calculating scale economies in (6) will vary depending on the restrictions imposed on the cost function in (2). The translog cost function does not constrain the structure of production to be homothetic, nor does it impose restrictions on the elasticities of substitution. These restrictions can be tested statistically. If any of the restrictions are valid, it is preferable to adopt the simplified model. If not, it is of interest to investigate the impact of their imposition on the shape of the estimated cost curves.A cost function corresponds to a homothetic production structure if, and only if, the cost function is separable in output and factor prices ${ }^{5}$. A homothetic production structure is further restricted to be homogeneous if, and only if, the elasticity of cost with respect to output is constant. For the translog cost function, the homotheticity and homogeneity restrictions are expressed as:

$$
\begin{array}{lll}
\text { Homotheticity: } & \gamma_{Y i}=0 \\
\text { Homogeneity: } & \gamma_{Y i}=0, \quad \gamma_{Y Y}=0
\end{array}
$$

The elasticities of substitution can all be restricted to unity by eliminating the secondorder terms in the input prices from the translog cost function. Thus the unitary elasticity of substitution cost is as follows:

$$
\text { Unit elasticity of substitution: } \quad \gamma_{i j}=0
$$

\section{Estimation Procedure}

It is feasible to estimate the parameters of the cost function using ordinary least squares ${ }^{6}$. However, this would neglect the information contained in the cost share equations (4) for capital and labour, which are also estimable. The now standard, more effective, and wellknown procedure, followed here, is to estimate the cost function jointly with the cost

\footnotetext{
${ }^{4}$ Hanoch (1975) discusses the elasticity of scale and the shape of average costs.

${ }^{5}$ See Diewert (1974) for formal statements and deviations of the restrictions for homotheticity and homogeneity. See also Caves and Christensen (1980) for globalproperties of flexible functional forms.

${ }^{6}$ This technique, used by Nerlove (1963), is certainly attractive from the point of view of simplicity.
} 
share equations. However, in the actual estimation procedure the share equation for labour is dropped to avoid a singular covariance matrix. Given that the sum of the input shares for the two share equations equals one, the sum of the error terms across the two equations will be zero at each observation, resulting in a singular variance-covariance matrix. The standard solution to the singularity problem is to drop one of the cost share equations from the estimation process ${ }^{7}$.

Regarding the error structure, additive disturbances are assumed for each of the cost and share equations. The error term for each industry cost function is assumed to be uncorrelated with any other industry's error term. Given that the share equations are derived via differentiation of the cost function, the share equation will not contain the error term for the cost function. However, in keeping with the Seemingly Unrelated Regression (SUR) format, the error terms for the cost and share equations for any one industry are assumed to be correlated due to the effect of exogenous shocks affecting both equations. Therefore, following Christensen and Greene, we have used a three stage least squares estimation (3SLS) procedure.

We conclude that the optimal procedure is to estimate the above cost function jointly with the cost share equation for capital. It not only adds degrees of freedom without adding any unrestricted regression parameters, but given the relationship between the share equation and the cost function, several cross equation restrictions can be placed on the parameters to increase the efficiency of the estimates. For example, the constant in the capital share equation must be equal to the coefficient on $\ln Y$ in the cost function. Furthermore as noted above, in order for the cost function to correspond to a wellbehaved production function, it must be homogeneous of degree one in the prices. The restrictions necessary for compliance with this condition were all imposed in this paper throughout.

In addition to the above conditions, one can test and then, if warranted, impose further restrictions regarding homotheticity, homogeneity and unitary elasticities of substitution between inputs. These restrictions take the form of setting certain coefficients in the cost and cost share equations to zero. Depending on the property restrictions imposed in above, four models are considered in this study. Model I corresponds to the unrestricted general one. Model II imposes homotheticity. Model III correspond to the Model II, but with assuming homogeneity. Model IV imposes homotheticity and homogeneity with unitary elasticities of substitution. All four models account for the rate of technological change represented by a time trend $(\mathrm{Z})$. The four variants of the translog cost function, distinguished by the restrictions imposed on the general model, together with the capital share equation, along with the implied definition of scale economies, are presented in Table 1.

Insert Table 1 about here

\footnotetext{
${ }^{7}$ A drawback to dropping one of the equations is that the estimates will not be invariant to the omitted equation. A remedy to this problem is the procedure outlined in Caves, Christensen and Tretheway (1984). They propose a modification of Zellner's (1962) SUR technique in which all equations are retained in the first stage but one is then dropped in the last stage of the estimation process.
} 
In these models the scale economies are both time and industry specific. It varies from one level of output to another and one time period to another. The scale economies and cost shares representing cost elasticities of inputs or responsiveness of cost to percentage changes in input prices varies across industries and over time and at each observation. In order to conserve space, the value reported in Appendix I and II is calculated at the mean of the independent variables. For the last two model specifications of the cost function (homothetic and homogeneous; and homothetic, homogeneous and unit elasticity of substitution) the estimate of scale economies is invariant with respect to the output level, however, it does vary with time due to the presence of this variable in the definition of the cost elasticity. For matters of sensitivity analysis the four models are also estimated by ignoring the technology variable $(\mathrm{Z})$.

\section{Data}

The data used in the empirical estimation of the four models outlined above comes from the economics research unit of the Tunisian Ministry of Plan, the Tunisian National Statistics Institute (INS, 2001 and 2005) and from the Quantitative Economy Institute (IEQ, 1998 and 2005). These data sets cover fifteenmajor sectors of the economy for the time period 1971-2004. It contains information on capital, labour, production, intermediate consumption, exports, imports, and prices for the above mentioned input factors of production. The data set was constructed by the Tunisian Ministry of Plan from documents published by the national statistical institute and is the databaseunderlying all official Ministry of Plan projections. The sectors included are agriculture \& fishing, food processing industry, textiles, clothing and leather industry, chemical industry, construction material, ceramic and glass industry, mechanical electric industry, and other manufacturing industry, mining, oil and gas industry, electricity, transport, tourism, water, building and public works, and services.

Most of the variables were available directly from the Tunisian database while others required either simplifications or references to secondary data sources. Total cost is assumed to consist entirely of variable costs. It was calculated as the sum of payments to labour and capital at the industry-specific market rate of return of these two factors, or $\mathrm{TC}=\mathrm{P}_{\mathrm{K}} \mathrm{K}+\mathrm{P}_{\mathrm{L}} \mathrm{L}$.

The cost of capital is equal to $\mathrm{P}_{K} \mathrm{~K}$, where $\mathrm{P}_{\mathrm{K}}$ is the price of capital assumed equal to the price of acquiring new capital or FBCFB (Prix de formation de capital fixe par branched'activite). Capital Stock $\mathrm{K}$ is assumed to be quasi-fixed in the short-run, following an investment decision. It is measured as the value of capital equipment. The cost of labour is equal to $\mathrm{P}_{\mathrm{E}} \mathrm{E}$, where $\mathrm{P}_{\mathrm{E}}$ is calculated by using the Wages defined as the average annual wage per worker obtained by dividing total wages in each industry by the total number of employees in that industry or service. Thus, the wage variable is industry/service-specific. The total employment $\mathrm{E}$ is the total number of employees in each industry or service. The output variable defined as value-added is measured as value of production less material and energy expenses.The technology is represented by a trend or year dummy variables. Wages, value-added, and capital stock are given in Tunisian dinars and are transferred to fixed 1990 prices using the producer price index. 


\section{Empirical Cost Function Results}

The cost function ignoring technology (equation 1) and technology (Z) considered as an input (equation2) jointly with the capital cost share (equation4) are estimated with and without homotheticity, homogeneity and unit elasticity of substitution restriction. The estimation results, in limited form to conserve spaces, are reported in Appendix I and II and discussed below. In order to conserve spaces we do not report the full estimation results for the time trend variable or its decomposed underlying components. A negative sign of the Z-variable indicates a negative shift in the cost function over time or technical progress, while a positive sign suggest technical regress. The non-neutral component indicates biased technical change.

Based on the results reported in the Appendix I (Translog Cost Function Results: Time considered as an input-like variable), the estimation of the cost function equation show that only Textiles and Building and Public Works are characterized by an increasing return to scale and have positive sign forthe variables $(\operatorname{lnY}, \operatorname{lnPk}$, and $\ln \mathrm{Pw})$ in all the models (model I, model II, model III, and model IV). Electricity, Transport, Mechanical and Oil and Gas industry, and Tourism are also characterized by an increasing return to scale and having a negative sign for the variables $\ln \mathrm{Y}$ or $\ln \mathrm{Pk}$ in at least one of the 4 models. The cost functions of the remaining 8 sectors including Chemicals, Diverse Manufacturing, Construction Materials, Services, Agriculture and Fishing, Food Processing Industry, Mining, Water shows a negative sign for two or more variables (lnY, $\ln \mathrm{Pk}, \ln \mathrm{Pw}$ ) in at least one of the models..

The results of the translog cost function: time not considered as an input-like variable (Appendix II), show that some sectors like electricity have a positive sign for $\ln Y$, $\ln P k$ and $\operatorname{lnPw}$ in all the models. Water and Diverse Manufacturing industry have only one variable (lnY or $\operatorname{lnPk}$ ) with a negative sign in one of the models at least, and are characterized by an increasing return to scale. Regarding Tourism, the cost function shows a negative sign for more than one variable.

\subsection{Time considered in the specification}

Appendix Ipresent a summary of the coefficients and the significance levels of each for the principal independent variables $\left(\mathrm{Y}, \mathrm{P}_{\mathrm{K}}\right.$ and $\left.\mathrm{P}_{\mathrm{W}}\right)$ as taken from the cost function equation. This Appendix alsoshows the estimates of the scale elasticity calculated at the mean values of the independent variables. Although the estimates of scale economies across different specifications of the cost function are relatively robust, several of the cost function parameter estimates have an unexpected negative sign or are only weakly significant. The negative signs, technology (Z) related coefficients being excepted, indicate violationsof regulatory conditions.

To facilitate interpretation and comparison across industrial sectors, Table 2 categorizes the results as "Good" (all coefficients with the correct a priori sign and are statistically significant), "Fair" (one coefficient with incorrect a priori sign and arestatistically insignificant), or "Poor" (two or more coefficients with the incorrect a priori sign and arestatistically insignificant). This classification seems to be ad hoc, but helps to shed lights on the performance of the various models. While most sectors show signs of 
increasing returns to scale, the unfortunate conclusion emerging from this table is that the specified translog cost function with time trend did not fit the data well for most sectors. This is indicated by the large number of sectors in the "Poor" category, implying that the estimated cost function for these sectors had several variables with a negative sign violating regulatory conditions. This is interpreted as an attempt to account for the rate of technical change which may lead to distortions in the models properties concerning fulfilment of the regulatory conditions.

\section{Insert Table 2 about here}

The results for Textiles, Building and Public Works were "Good" in the sense that all variables presented a positive sign and were statistically significant, but these two sectors appear to be characterized by an increasing return to scale. The industries falling into the "Fair" category all show a sign of increasing returns to scale. Electricity, Transport, Mechanical and Oil and Gas industry are all primarily public enterprises with few private firms and preferential treatment regarding external trade policy. For several sectors in the "Fair" category, the estimated cost elasticity is negative. Generally, this is the result of a negative coefficient on $\ln Y$ and the interaction term $Z^{*} \ln Y$. This effect forces the scales to be negative and it decreases the estimated scale for several sectors.

\subsection{Time not considered in the specification}

Several explanations are possible for the weak results presented above, principallyamong which is probably multicollinearity. A priori, given the large number of independent variables (many of which are the product of squares and interactions of independent variables) and the small size of the data set, one should expect multicollinearity to be a major problem. The dataset spans the years from 1971 to 2004 or 34 observations per equation, which translates into 68 observations for both the cost and capital share equations. The unrestricted translog model contains 20 parameters, of which 15 are unique (the other five being restricted across equations). To these the intercept and variance are to be added. Multicollinearity negatively impacts the results due to the high degree of linearity between independent variables results in imprecise individual parameter estimates and it renders the results sensitive to small changes in the equation specification. As one might expect in a model with few degrees of freedom and many interaction variables, evidence of multicollinearity abounds. ${ }^{8}$

As is well known, the presence of multicollinearity does not invalidate the estimates, but the robustness of the estimates and their precision is in question as the effects are confounded. For the part, the standard errors of the scale estimates are sufficiently small to be able to reject the hypothesis of constant returns to scale for many sectors. However, the estimated coefficients do occasionally change both in magnitude and in sign. One way to reduce the degree of linear dependence amongst the right-hand side variables is to

\footnotetext{
${ }^{8}$ Intuitively, the presence of so many interaction terms when the degrees of freedom were low led us to suspect multicollinearity. This suspicion was confirmed by an analysis of the principal componentsof the $\mathrm{X}^{\prime} \mathrm{X}$ matrix, where $\mathrm{X}$ is the data matrix of right-hand side variables. Several of the time trend interaction terms $\left(\mathrm{Z} * \ln \mathrm{Y}, \mathrm{Z} * \ln \mathrm{P}_{\mathrm{K}}, \mathrm{Z} * \ln \mathrm{P}_{\mathrm{L}}\right.$ ) had very small characteristic roots (of the order of $10^{-4}$ ), which is considered evidence of multicollinearity.
} 
use a functional form with fewer parameters. ${ }^{9}$ Consider the results of estimating a variant of the original translog cost function specified above with the square and interaction terms for Z-variable omitted. This reduces the number of unique parameters to 11 and the number of restricted parameters to 4 . In translog form, this cost function is expressed as:

$$
\begin{aligned}
\ln T C=\alpha_{0} & +\alpha_{Y} \ln Y+1 / 2 \gamma_{Y Y}(\ln Y)^{2}+\sum_{i} \alpha_{i} \ln P_{i}+1 / 2 \sum_{i} \sum_{j} \gamma_{i j} \ln P_{i} \ln P_{j} \\
& +\sum_{i} \gamma_{Y i} \ln Y \ln P_{i}+\alpha_{t} Z+\varepsilon
\end{aligned}
$$

The estimation procedure is the same as outlined above, i.e., joint estimation of the cost function (9) with the capital share equation (4), imposing the necessary within and across equation restrictions for a well-behaved cost function. The results of estimating this simplified model variant are more favourable relative to the specification where time trend enters non-linearly in form of squares and interactions with other explanatory variables (Appendix II).

To aid in interpretation, in similarity with the previous results, the results based on time trend (Z) not considered as an input-likevariable are categorized in Table 3 as "Good", "Fair”, and "Poor” based on sign and significance of the explanatory variables.

Insert Table 3 about here

Results from Table 3 show that with the $\mathrm{Z}$ interaction terms dropped, good results are obtained for Electricity (ELEC), but the result for Water and Construction Materials (MCV) were classified as fair. The translog cost function without $\mathrm{Z}$ interaction terms fit the data well for the Electricity, Building and Public Works, and Textiles with the hypothesis of increasing returns to scale. As before, all sectors in the "Fair" category show signs of increasing returns to scale. The remaining sectors in the "Fair" category are primarily public enterprises (like Hydrocarbon) with few private firms.

For Chemicals and Food processing Industries, the scale estimate for both sectors indicates increasing returns to scale but, given the poor quality of the estimates, the case for modelling them as IRS cannot rely solely on the empirical evidence. Rather, it should be evaluated in the light of other stylized facts regarding industry structure and import protection. ${ }^{10}$ The question of which of the four functional models outperforms the others can be answered by referencing the t-statistics on selected coefficients. For example, a homothetic cost function is observed whether the coefficients on $\ln Y^{*} \ln P_{K}$ and $\ln Y^{*} \ln P_{L}$ are statistically insignificant, i.e. statistically not different from zero. A homogeneous

\footnotetext{
${ }^{9}$ An alternative sensitivity analysis concerning the impact of reducing the number of parameters to be estimated can be made by analyzing the regression coefficients from the less complex translog cost function. In general, as the number of parameters decreases (as we move toward the homothetic, homogeneous, and unit elasticity of substitution form) the signs on the independent variables tend more toward their a priori value and their significance increases. The model reduces to a generalized CobbDouglas form with squares but without interaction terms.

${ }^{10}$ The presence of high import tariffs and large numbers of domestic firms in an industry does not by itself constitute evidence of increasing returns to scale; it does however show evidence of practice of liberalization policy.
} 
cost function is observed by homotheticity and a statistically insignificant coefficient on $1 / 2(\operatorname{Ln} Y)^{2}$.

Table 4 groups the industrial sectors by the functional forms and analysis of the regression coefficients. Only the alternatives for the translog cost function without Zinteraction terms (9) are considered here.

\section{Insert Table 4 about here}

The results of estimating this cost function indicate that the unrestricted model includes the entire "Fair" category and some of "Good" category with increasing returns to scale. But the estimation of the Homothetic, homogeneous and unit elasticity of substitution model indicate that the functional form includes the entire "Poor" category and some of the sectors classified as "Fair".

\subsection{Comparison with previous results}

Our finding that Textiles, Building and Public Works were classified as "Good" and appear to be characterized by an increasing return to scale seems different with Kress' (1994) finding based on Tunisian data. In fact, Kress findsthat the construction materials industry were good and characterized by constant returns to scale as this null hypothesis could not be rejected. Electricity, Transport, Mechanical and Oil and Gas industry show an increasing return to scale. They are all primarily public enterprises with few private firms.

In summary, we find that the translog cost function, without Z-interaction terms, fits the data well in particular for sectors that are consisting of primarily public enterprises and few private firms. The results from Kress (1994) indicate that several sectors where the estimated cost function did not fit the data particularly well, are nonetheless logical candidates for being modelled as increasing returns to scale sectors.

The difference can be explained by the measures that have been used to liberalize the economy which affected the competitiveness of the companies, and by the process of restructuration and privatization.

\section{Conclusion}

Empirical investigations of trade liberalization are conducted under the assumptions of increasing returns to scale and imperfect competition without testing for the presence of increasing return to scale prior to the analysis. This paper, by specifying a translog cost function and rigorous testing procedures, seeks to test whether evidence of increasing returns to scale at the Tunisian industry level can be found and to identify those sectors most likely characterized by increasing returns to scale. In addition to establishing the appropriateness of the result and its usefulness concerning the IRS/IC investigations of trade liberalization and its effects, the result will be useful in preparation for the construction of a Computable General Equilibrium model of trade liberalization.

With the Tunisian data (1971-2004) and rigorous testing procedures we investigate evidence of IRS at the industry level. Using an econometric approach based on the 
estimation of the translog cost function, we identify the sectors characterized by increasing returns to scale. The classification of the results shows that specification of the model is found to be sensitive to inclusion of time trend representing technology. The model accounting for technology did not fit the data well for most sectors. The estimation results without time trend interaction with other explanatory variable are different. Here most of the sectors show signs of increasing returns to scale.

Two conclusions emerge from this study. First, we find that the estimation results based on the translog cost function with technology considered as an input-like explanatory variable, indicates that the estimates of scale economies across different model specifications are relatively robust. While most sectors show signs of increasing returns to scale, the unfortunate conclusion emerging is that the specified translog cost function with time trend did not fit the data well for most sectors. This is indicated by the large number of sectors in the "Poor" category, implying that the estimated cost function for these sectors had several variables with statistically insignificant or negative sign violating the regulatory conditions.

Second and because of the weak results of the estimation, several explanations are possible, principal among which is probably multicollinearity. This multicollinearity negatively impacts the results in that the high degree of linearity between independent variables results in imprecise parameter estimates and renders the results sensitive to small changes in the model specification. As one might expect in a model with few degrees of freedom and many interaction terms, evidence of multicollinearity abounds. It should be noted that, the presence of multicollinearity does not invalidate the estimates, but the robustness of the estimates and their precision is questioned. As a result of dropping the time trend interaction terms "Good" results are obtained. The restricted translog cost function fit the data well for the Electricity, Building and Public Works, and Textiles with the hypothesis of increasing returns to scale confirmed.

All sectors in the "Fair" category show signs of increasing returns to scale. For Chemicals and Food processing Industries, the scale estimate indicates increasing returns to scale, but given the poor quality of the estimates, a modelling of them as increasing returns to scale cannot rely solely on the empirical evidence. Rather, it should be evaluated in the light of other stylized facts regarding industry structure and import protection. The results of estimating this cost function combined with information on industry structure help us to identify the sectors to be modelled under the assumption of increasing returns to scale.

We can conclude that the translog cost function fit well the industries data. In the course of liberalization period the Tunisian industries has experienced a major change in their returns to scale. The returns to scale tend to increase specifically in sector with many public enterprises and few private enterprises. 


\section{References}

Antle, J., and C. Crissman. 1988. The Market for Innovations and Short-Rrun Technological Change: Evidence from Egypt.Economic Development and Cultural Change36 (4): 669-690.

Aw, B. 1990. Estimating the Effect of Restrictions in Imperfectly Competitive Markets.Working Paper, 3-90-3Penn University.

Belkhairia, A. 1994. Les mesures de libéralisation du commerce extérieuretleur impact surl'équilibre de la balance externe de la Tunisie. Revue tunisienned'Economie, 5.

Boudhiaf, M. 2000. Politiquetunisienned'ouverture commercial.Perspectives de l'économietunisiennedans le cadre de l'ouverturerégionale.Séminaireinternational, IRD, Tunis.

Caves, D., and L. Christensen. 1980. Global Properties of Flexible Functional Forms. American Economic Review, 70 (3): 422-432.

Caves, D., L. Christensen, and J. Swanson. 1980. Productivity Growth in U.S. Railroads, 1951-74. Bell Journal of Economics 11: 166-181.

Caves, D., L. Christensen, and J. Swanson. 1981. Productivity Growth, Scale Economies and Capacity Utilisation in U.S. Railroads, 1954-74. American Economic Review 71 (5): 994-1002.

Caves, D., L. Christensen, and M. Tretheway. 1984. Economies of Density versus Economies of Scale: Why Trunk and Local Service Airline Costs Differ. Rand Journal of Economics 15 (4): 471-489.

Christensen, L., D.W. Jorgenson, and L. Lau. 1973. Transcendental Logarithmic Production Frontiers. Review of Economics and Statistic 55 (1): 28-45.

Christensen, L. and W.H. Greene. 1976. Economies of Scale in U.S. Electric Power Generation. Journal of Political Economy 84 (4): 655-676.

De Melo, J. and Roland-Holst. 1990. Industrial Organization and Trade Liberalization. PRE Working Paper, $\mathrm{n}^{\circ}$ WPS518, Country Economics department, The World Bank.

Devarajan, S. and D. Rodrik. 1989. Trade Liberalization in Developing Countries: Do Imperfect Competition and Scale Economies Matter?.American Economic Review 79: 283-287.

Devarajan, S. and D. Rodrik. 1991. Pro-competitive Effects of Trade Reform: Results from a CGE Model of Cameroon. European Economic Review 35(5): 1157-1184.

Diewert, W.E. 1974. Functional Forms for Revenue and Factor Requirement Functions.International Economic Review15: 119-130.

Diewert, W. and T. Wales. 1987. Flexible Functional Forms and Global Curvature Conditions. Econometrica 55 (1): 43-68.

Dixit, A. and V. Norman. 1980.Theory of International Trade. Cambridge: Cambridge University Press).

Ethier, W. 1982. National and International Returns to Scale in the Modern Theory of International Trade. American Economic Review 72: 389-405.

Friedlaender, A., C. Winston, and K. Wang. 1983. Costs, Technology and Productivity in the U.S Automobile Industry. Bell Journal of Economic 14: 1-20.

Gunasekera, H.D. and R. Tyers. 1991. Imperfect Competition and Returns to Scale in a Newly Industrializing Economy. Journal of Development Economics 34: 223-247. 
Gupta, K. and M.Taher. 1984. Technological Progress and Factor Substitution in the U.S. Textile Industry: 1949-74. Empirical Economics 9: 67-74.

Hanoch, G. 1975. The Elasticity of Scale and the Shape of Average Costs.American Economic Review65(3): 492-497.

Harris, R. 1984. Applied General Equilibrium Analysis of Small Open Economies with Scale Economies and Imperfect Competition.American Economic Review 74(5): 1016-1033.

Hertel, T. 1991. Assessing the Effects of Trade Policy Liberalization in the Presence of Imperfect Competition: Theoretical Insights into Empirical Findings.Working Paper.

Heshmati, A. 2003. Productivity Growth, Efficiency and Outsourcing in Manufacturing and Services. Journal of Economic Surveys 17(1): 79-112.

IEQ. 1998. Les statistiques de l'Institutd'Economie Quantitative, Tunis

IEQ. 2005. Les statistiques de l'Institutd'Economie Quantitative, Tunis.

INS,Institut National de Statistique.2001. Les Comptes de la Nation, Tunis.

INS, Institut National de Statistique.2005. Les Comptes de la Nation, Tunis.

Kress, D. 1994.Trade Libéralization in Tunisia: A General Equilibrium Analysis. Dissertation, North Carolina University.

Krugman, P. 1979. Increasing Returns, Monopolistic Competition and International Trade.Journal of International Economics 9: 469-479.

Lancaster, K. 1980. Intra-Industry Trade under Perfect Monopolistic Competition. Journal of International Economics 10: 151-175.

List, J. and H. Zhou. 2007. Internal Increasing Returns to Scale and Economic Growth. NBER Working Paper, 12999.

Markusen, J. and A. Venables. 1988. Trade Policy with Increasing Returns and Imperfect Competition: Contradictory Results from Competing Assumptions. Journal of International Economics 24: 299-316.

McDonough, L. 1992. Homothetic and Non-Homothetic Scale Economies in Applied General Equilibrium Analysis.Canadian Journal of Economics 25 (1): 196-210.

Nerlove, M. (1963).Returns to Scale in Electricity Supply. (In Measurement in Economics Studies in Mathematical Economics and Econometrics in Memory of Yehuda Grunfeld, Carl , F. (edits), California: Stanford University Press).

Shephard, R. W. 1953. Cots and Production Functions. Princeton, N. J: Princeton University Press.

Zellner, A. 1962.An Efficient Method for Estimating Seemingly Unrelated Regressions and Tests for Aggregation Bias.Journal of American Statistical Association 57: 585-612. 
Table 1. The different cost model specification

\begin{tabular}{|c|c|c|c|}
\hline $\begin{array}{l}\text { Model and } \\
\text { restriction }\end{array}$ & Cost function & Capital cost share & Scale elasticity \\
\hline Model I & $\begin{aligned} \ln T C= & \alpha_{0}+\alpha_{Y} \ln Y+1 / 2 \gamma_{Y Y}(\ln Y)^{2}+\sum_{i} \alpha_{i} \ln P_{i} \\
& +1 / 2 \sum_{i} \sum_{j} \gamma_{i j} \ln P_{i} \ln P_{j}+\sum_{i} \gamma_{Y i} \ln Y \ln P_{i} \\
& +\alpha_{t} Z+1 / 2 \gamma_{t t} Z^{2}+\gamma_{t Y} Z \ln Y+\sum_{i} \gamma_{t i} Z \ln P_{i}\end{aligned}$ & $\begin{aligned} S_{K}= & \alpha_{K}+\sum_{j} \gamma_{i j} \ln P_{j} \\
& +\gamma_{Y 1} \ln Y+\gamma_{t k} Z\end{aligned}$ & $\begin{array}{l}\text { Scale }=\alpha_{Y}+\gamma_{Y Y}(\ln Y) \\
\quad+\sum_{i} \gamma_{Y i} \ln P_{i}+\gamma_{t Y} Z\end{array}$ \\
\hline $\begin{array}{l}\text { Model II } \\
\gamma_{Y i}=0\end{array}$ & $\begin{aligned} \ln T C= & \alpha_{0}+\alpha_{Y} \ln Y+1 / 2 \gamma_{Y Y}(\ln Y)^{2}+\sum_{i} \alpha_{i} \ln P_{i} \\
& +1 / 2 \sum_{i} \sum_{j} \gamma_{i j} \ln P_{i} \ln P_{j}+\alpha_{t} Z+1 / 2 \gamma_{t t} Z^{2} \\
& +\gamma_{t Y} Z \ln Y+\sum_{i} \gamma_{t i} Z \ln P_{i}\end{aligned}$ & $\begin{aligned} S_{K}= & \alpha_{K}+\sum_{j} \gamma_{i j} \ln P_{j} \\
& +\gamma_{t k} Z\end{aligned}$ & $\begin{aligned} \text { Scale }= & \alpha_{Y}+\gamma_{Y Y}(\ln Y) \\
& +\gamma_{t Y} Z\end{aligned}$ \\
\hline $\begin{array}{l}\text { Model III } \\
\gamma_{Y i}=0, \gamma_{Y Y}=0\end{array}$ & $\begin{aligned} \ln T C= & \alpha_{0}+\alpha_{Y} \ln Y+\sum_{i} \alpha_{i} \ln P_{i} \\
& +1 / 2 \sum_{i} \sum_{j} \gamma_{i j} \ln P_{i} \ln P_{j} \\
& +\alpha_{t} Z+1 / 2 \gamma_{t t} Z^{2}+\gamma_{t Y} Z \ln Y+\sum_{i} \gamma_{t i} Z \ln P_{i}\end{aligned}$ & $\begin{aligned} S_{K}= & \alpha_{K}+\sum_{j} \gamma_{i j} \ln P_{j} \\
& +\gamma_{t k} Z\end{aligned}$ & Scale $=\alpha_{Y}+\gamma_{t Y} Z$ \\
\hline $\begin{array}{l}\text { Model IV } \\
\gamma_{Y i}=0, \gamma_{Y Y}=0 \\
\text { and } \gamma_{i j}=0\end{array}$ & $\begin{aligned} \ln T C= & \alpha_{0}+\alpha_{Y} \ln Y+\sum_{i} \alpha_{i} \ln P_{i}+\alpha_{t} Z+1 / 2 \gamma_{t t} Z^{2} \\
& +\gamma_{t Y} Z \ln Y+\sum_{i} \gamma_{t i} Z \ln P_{i}\end{aligned}$ & $S_{K}=\alpha_{K}+\gamma_{t k} Z$ & Scale $=\alpha_{Y}+\gamma_{t Y} Z$ \\
\hline
\end{tabular}

Glossary of variables: TC=total cost, Y-value added, $\mathrm{P}=$ input prices, $\mathrm{S}=$ input cost shares, $\mathrm{Z}=$ technology (represented by a time trend). 
Table 2 .Classification of Cost Function Results: Time considered as an input-like variable

\begin{tabular}{|c|c|c|}
\hline “Good” Results & "Fair” Results & "Poor” Results \\
\hline IRS & IRS & Chemical \\
\hline Textiles & Oil and Gas Industry & Diverse Manufacturing \\
\hline Building and Public Works & Mechanical and Electrical & Construction Materials \\
\hline & Electricity & Services \\
\hline & Transport & Agriculture and Fishery \\
\hline & Tourism & Food Processing Industry \\
\hline & & Mining \\
\hline & & Water \\
\hline
\end{tabular}

Note: The translog cost model and cost shares are estimated including Z, it's square and interactions.

Table 3.Classification of Cost Function Results: Time not considered as an input-like variable

\begin{tabular}{|c|c|c|}
\hline “Good” Results & "Fair” Results & "Poor” Results \\
\hline IRS & IRS & \\
\hline Electricity & Diverse Manufacturing & Food Processing Industry \\
\hline Building and Public Works & Mechanical and Electrical & Chemical \\
\hline Textiles & Construction Materials & Mining \\
\hline & Oil and Gas Industry & Services \\
\hline & Transport & Tourism \\
\hline & Water & Agriculture and Fishery \\
\hline
\end{tabular}

Note: The translog cost model and cost shares are estimated without the $\mathrm{Z}$ variable.

Table 4. Classification of Industries by Functional Form

\begin{tabular}{|l|l|l|l|}
\hline $\begin{array}{l}\text { Model I } \\
\text { Unrestricted Model }\end{array}$ & $\begin{array}{l}\text { Model II } \\
\text { Homothetic Model }\end{array}$ & $\begin{array}{c}\text { Model III } \\
\text { Homothetic and } \\
\text { Homogeneous Model }\end{array}$ & $\begin{array}{c}\text { Model IV } \\
\text { Homothetic, } \\
\text { Homogeneous and Unit } \\
\text { Elasticity of Substitution }\end{array}$ \\
\hline Agriculture \& Fishery & Food Processing & Tourism & Chemicals \\
\hline $\begin{array}{l}\text { Construction Materials } \\
\text { Elechanical and }\end{array}$ & & & Water \\
\hline Textile Industry & & & $\begin{array}{l}\text { Building and public } \\
\text { Works }\end{array}$ \\
\hline Diverse Manufacturing & & & Services \\
\hline Mining & & & \\
\hline Oil and Gas Industry & & & \\
\hline Electricity & & & \\
\hline Transport & & & \\
\hline
\end{tabular}


Appendix I: TranslogCost Function Results: Time considered as an input-like variable

\begin{tabular}{|c|c|c|c|c|}
\hline Coefficients & Model I & Model II & Model III & Model IV \\
\hline \multicolumn{5}{|c|}{ 1.Agriculture and Fishery: } \\
\hline $\ln \mathrm{Y}$ & -4.8595 & -4.8366 & -0.0318 & 0.0399 \\
\hline t-value & $(-1.4153)$ & $(-1.4023)$ & $(-0.5462)$ & $(0.6699)$ \\
\hline $\ln \mathrm{PK}$ & -0.0004 & -0.1405 & -0.1428 & 0.2699 \\
\hline t-value & $(-0.0012)$ & $(-0.9561)$ & $(-0.9677)$ & $(22.4925)$ \\
\hline $\operatorname{lnPW}$ & 1.0004 & 1.1405 & 1.1428 & 0.7300 \\
\hline t-value & $(2.9616)$ & (7.7606) & $(7.7444)$ & $(60.8206)$ \\
\hline Scale & 0.0097 & 0.0223 & 0.0169 & 0.0370 \\
\hline Stderror & $(0.0809)$ & $(0.0815)$ & $(0.0276)$ & $(0.0017)$ \\
\hline \multicolumn{5}{|c|}{ 2. Food Processing: } \\
\hline $\ln \mathrm{Y}$ & 32.1781 & 32.2104 & 0.1204 & 0.0441 \\
\hline t-value & (1.0775) & (1.0783) & $(0.4165)$ & $(0.2847)$ \\
\hline $\ln P K$ & -0.0865 & -0.0779 & -0.0939 & 0.2160 \\
\hline t-value & $(-0.3850)$ & $(-0.4248)$ & $(-0.5112)$ & $(11.4834)$ \\
\hline $\operatorname{lnPW}$ & 1.0865 & 1.0779 & 1.0939 & 0.7839 \\
\hline t-value & $(4.8382)$ & $(5.8781)$ & (5.9581) & $(41.6711)$ \\
\hline Scale & -0.1773 & -0.1751 & -0.2316 & -0.0850 \\
\hline Stderror & $(0.4871)$ & $(0.4876)$ & $(0.1994)$ & $(0.0731)$ \\
\hline \multicolumn{5}{|c|}{ 3. Construction Materials: } \\
\hline $\ln Y$ & 0.7248 & -0.2223 & 0.4619 & 0.2801 \\
\hline t-value & $(0.5578)$ & $(-0.1794)$ & (4.3909) & (2.3868) \\
\hline $\ln P K$ & 0.0711 & -2.7337 & -2.7634 & 0.2953 \\
\hline t-value & $(0.1764)$ & $(-2.5632)$ & $(-2.6167)$ & (8.2193) \\
\hline $\operatorname{lnPW}$ & 0.9288 & 3.7337 & 3.7635 & 0.7047 \\
\hline t-value & (2.3029) & (3.5008) & (3.5636) & (19.6172) \\
\hline Scale & 1.7719 & 0.5403 & 0.5465 & 0.4889 \\
\hline Stderror & $(0.2825)$ & $(0.0711)$ & $(0.0479)$ & $(0.1183)$ \\
\hline \multicolumn{5}{|c|}{ 4. Mechanical and Electrical: } \\
\hline$\overline{\ln Y}$ & 5.3183 & 5.3301 & -0.1683 & -0.1717 \\
\hline t-value & $(5.2689)$ & $(5.4309)$ & $(-3.1089)$ & $(-3.2371)$ \\
\hline $\operatorname{lnPK}$ & 0.8636 & 0.7505 & 0.7426 & 0.2317 \\
\hline t-value & $(2.6626)$ & $(2.3533)$ & $(2.0087)$ & $(17.8816)$ \\
\hline $\ln \mathrm{PW}$ & 0.1363 & 0.2495 & 0.2573 & 0.7683 \\
\hline t-value & $(0.4204)$ & $(0.7822)$ & $(0.6961)$ & (59.2846) \\
\hline Scale & 0.2943 & 0.3413 & 0.2669 & 0.2933 \\
\hline Stderror & $(0.4981)$ & $(0.5133)$ & $(0.2465)$ & $(0.2635)$ \\
\hline \multicolumn{5}{|l|}{ 5. Chemical: } \\
\hline $\ln \mathrm{Y}$ & -2.9334 & -3.5384 & -0.2506 & -0.1686 \\
\hline t-value & $(-1.5593)$ & $(-1.9263)$ & $(-2.1439)$ & $(-1.43590$ \\
\hline $\ln \mathrm{PK}$ & -2.5506 & -1.8381 & -1.8777 & 0.3419 \\
\hline t-value & $(-5.0996)$ & $(-4.2473)$ & $(-4.3837)$ & (12.0075) \\
\hline $\operatorname{lnPW}$ & 3.5506 & 2.8381 & 2.8777 & 0.6581 \\
\hline t-value & (7.0991) & (6.5581) & (6.7183) & (23.1135) \\
\hline Scale & 0.2137 & 0.1981 & 0.1600 & 0.4099 \\
\hline Stderror & $(0.3026)$ & (0.3078) & $(0.2326)$ & $(0.3277)$ \\
\hline \multicolumn{5}{|l|}{ 6. Textiles: } \\
\hline $\ln Y$ & 4.3496 & 2.6069 & 0.1015 & 0.1032 \\
\hline t-value & (3.1930) & (1.8756) & $(2.2506)$ & (2.2147) \\
\hline $\operatorname{lnPK}$ & 0.2442 & 0.6507 & 0.6530 & 0.0914 \\
\hline t-value & (2.3878) & (5.2104) & (5.4653) & (11.6288) \\
\hline $\operatorname{lnPW}$ & 0.7558 & 0.3493 & 0.3470 & 0.9086 \\
\hline t-value & (7.3931) & (2.7976) & (2.9048) & (115.5651) \\
\hline
\end{tabular}




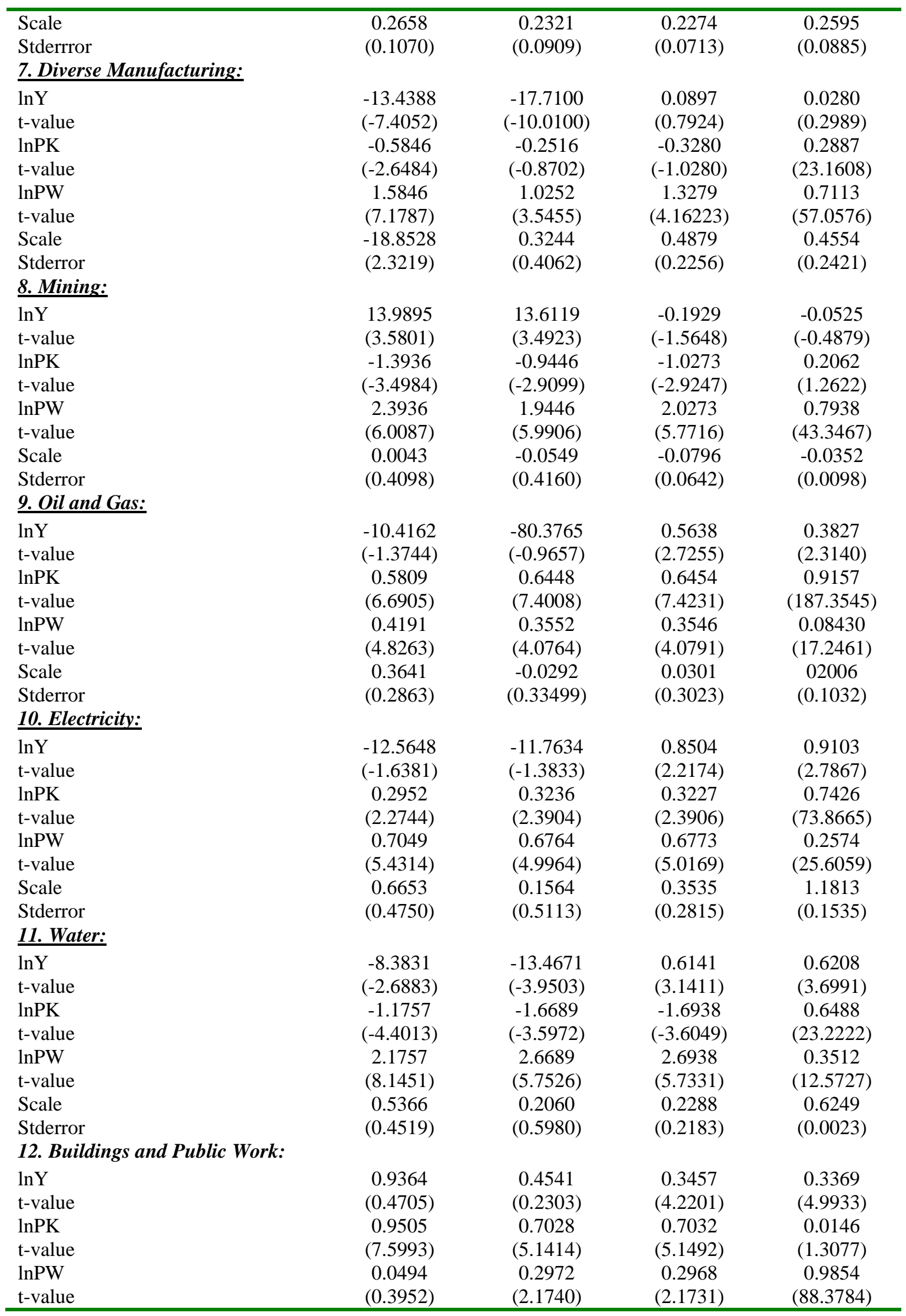




\begin{tabular}{|c|c|c|c|c|}
\hline $\begin{array}{l}\text { Scale } \\
\text { Stderror } \\
\text { 13. Trans }\end{array}$ & $\begin{array}{c}0.3713 \\
(0.0196)\end{array}$ & $\begin{array}{c}0.2985 \\
(0.0247)\end{array}$ & $\begin{array}{c}0.2989 \\
(0.0265)\end{array}$ & $\begin{array}{c}0.2797 \\
(0.0324)\end{array}$ \\
\hline \multicolumn{5}{|c|}{ 13. Transport: } \\
\hline $\begin{array}{l}\operatorname{lnY} \\
\text { t-value }\end{array}$ & $\begin{array}{l}11.1055 \\
(1.2031)\end{array}$ & $\begin{array}{l}11.4710 \\
(1.2583)\end{array}$ & $\begin{array}{c}0.1925 \\
(0.8119)\end{array}$ & $\begin{array}{c}0.3561 \\
(1.7329)\end{array}$ \\
\hline $\operatorname{lnPK}$ & -0.1011 & 0.2243 & 0.2919 & 0.4039 \\
\hline t-value & $(-0.1781)$ & $(0.5864)$ & $(0.7845)$ & (31.2117) \\
\hline $\operatorname{lnPW}$ & 1.1011 & 0.7757 & 0.7081 & 0.5961 \\
\hline t-value & (1.9393) & (20.0274) & (1.9028) & (46.0691) \\
\hline Scale & 0.5140 & 0.3923 & 0.3968 & 0.4605 \\
\hline Stderror & $(0.2288)$ & $(0.2513)$ & (0.1158) & $(0.0591)$ \\
\hline \multicolumn{5}{|c|}{ 14. Tourism: } \\
\hline $\ln \mathrm{Y}$ & 3.7531 & 3.7608 & 0.1372 & -0.1464 \\
\hline t-value & (0.4779) & $(0.4821)$ & $(0.5977)$ & $(-0.9505)$ \\
\hline $\operatorname{lnPK}$ & 3.0273 & 2.9323 & 2.9327 & 0.6303 \\
\hline t-value & (25.2022) & (36.3938) & (36.3803) & (21.7561) \\
\hline $\operatorname{lnPW}$ & -2.0273 & -1.9323 & -1.9327 & 0.3697 \\
\hline t-value & $(-16.877)$ & $(-23.9826)$ & $(-23.9754)$ & (12.7599) \\
\hline Scale & 0.1010 & 0.1092 & 0.1461 & 0.0331 \\
\hline Stderror & $(0.1014)$ & (0.0991) & $(0.0051)$ & (0.1017) \\
\hline \multicolumn{5}{|c|}{ 15. Services: } \\
\hline $\ln Y$ & -86.5763 & -86.5434 & -0.5303 & -0.4108 \\
\hline t-value & $(-2.1700)$ & $(-2.1715)$ & $(-2.2284)$ & $(-1.2260)$ \\
\hline $\operatorname{lnPK}$ & 1.6624 & 1.6756 & 1.6754 & 0.0920 \\
\hline t-value & (2.1586) & (12.6315) & (12.5878) & (4.6993) \\
\hline $\operatorname{lnPW}$ & -0.6623 & -0.6756 & -0.6754 & 0.9080 \\
\hline t-value & $(-0.8601)$ & $(-5.0928)$ & $(-5.0743)$ & (46.3993) \\
\hline Scale & 0.0329 & 0.3059 & -0.04790 & 0.0898 \\
\hline Stderror & $(0.4755)$ & $(0.4755)$ & $(0.2733)$ & $(0.2836)$ \\
\hline
\end{tabular}


AppendixII:Translog Cost Function Results: Time not considered as an input-like variable

\begin{tabular}{|c|c|c|c|c|}
\hline Coefficients & Model I & Model II & Model III & Model IV \\
\hline \multicolumn{5}{|c|}{ 1.Agriculture and Fishery: } \\
\hline $\ln \mathrm{Y}$ & -3.8056 & -0.7455 & 0.0355 & 0.0433 \\
\hline t-value & $(-3.0055)$ & $(-0.6524)$ & $(1.0846)$ & $(0.5813)$ \\
\hline $\ln \mathrm{PK}$ & -2.2066 & -1.0278 & -1.0216 & 0.6805 \\
\hline t-value & $(-7.1746)$ & $(-12.3475)$ & $(-12.1779)$ & (19.1917) \\
\hline $\ln P W$ & 3.2066 & 2.0278 & 2.0216 & 0.3195 \\
\hline t-value & (10.4259) & $(12.8101)$ & $(24.0985)$ & $(9.0106)$ \\
\hline Scale & 0.2505 & 0.0418 & 0.0355 & 0.0433 \\
\hline Stderror & $(0.0523)$ & $(0.0227)$ & $(0.0327)$ & $(0.0745)$ \\
\hline \multicolumn{5}{|c|}{ 2. Food Processing: } \\
\hline $\ln Y$ & 14.438 & -3.4251 & 0.00308 & -0.0036 \\
\hline t-value & $(5.8060)$ & $(-4.0942)$ & $(0.0311)$ & $(-0.0277)$ \\
\hline $\operatorname{lnPK}$ & -0.1733 & 2.1779 & 2.4838 & 0.5219 \\
\hline t-value & $(-0.5148)$ & $(22.1240)$ & (19.2305) & $(15.8151)$ \\
\hline $\operatorname{lnPW}$ & 1.1733 & -1.1779 & -1.4838 & 0.4781 \\
\hline t-value & $(3.4850)$ & $(-18.0733)$ & $(-11.4882)$ & (14.4869) \\
\hline Scale & -0.3703 & 0.1314 & 0.0031 & -0.0036 \\
\hline Stderror & $(0.9727)$ & $(0.2195)$ & $(0.0991)$ & $(0.1289)$ \\
\hline \multicolumn{5}{|c|}{ 3. Construction Materials: } \\
\hline $\ln Y$ & 3.0642 & 1.9871 & 0.8979 & 0.5484 \\
\hline t-value & (10.8828) & (3.6040) & (11.8338) & $(12.1532)$ \\
\hline $\ln P K$ & -0.7883 & -2.3029 & -2.5714 & 0.6490 \\
\hline t-value & $(-2.5577)$ & $(-5.6184)$ & $(-5.6388)$ & $(16.0532)$ \\
\hline $\ln \mathrm{PW}$ & 1.7883 & 3.3029 & 3.5714 & 0.3510 \\
\hline t-value & $(5.8025)$ & $(8.0580)$ & (7.8316) & (8.6814) \\
\hline Scale & 1.2638 & 0.6968 & 0.8979 & 0.5484 \\
\hline Stderror & $(0.1003)$ & $(0.2206)$ & $(0.0759)$ & $(0.0451)$ \\
\hline \multicolumn{5}{|c|}{ 4. Mechanical and Electrical: } \\
\hline $\ln Y$ & $3 . .9794$ & 2.3651 & 0.6583 & 0.3006 \\
\hline t-value & $(8.9975)$ & $(4.4254)$ & $(6.5586)$ & $(7.8271)$ \\
\hline $\operatorname{lnPK}$ & -0.7872 & -1.2439 & -0.6104 & 0.5204 \\
\hline t-value & $(-2.7044)$ & $(-5.4627)$ & $(-2.8291)$ & (18.1695) \\
\hline $\ln P W$ & 1.7872 & 2.2439 & 1.6104 & 0.4796 \\
\hline t-value & $(6.1400)$ & $(9.8543)$ & (7.4641) & (16.7469) \\
\hline Scale & 0.7191 & 0.2374 & 0.6583 & 0.3006 \\
\hline Stderror & $(0.0829)$ & $(0.2611)$ & $(0.1004)$ & $(0.0384)$ \\
\hline \multicolumn{5}{|l|}{ 5. Chemical: } \\
\hline $\ln Y$ & 1.9757 & 3.0353 & -0.0427 & 0.0925 \\
\hline t-value & (4.3129) & (5.4643) & $(-0.5065)$ & $(1.4220)$ \\
\hline $\ln \mathrm{PK}$ & -2.8935 & -2.3608 & -3.7501 & 0.6849 \\
\hline t-value & $(-6.0611)$ & $(-5.2851)$ & $(-6.3210)$ & (18.2373) \\
\hline $\operatorname{lnPW}$ & 3.8935 & 3.3608 & 4.7501 & 0.3151 \\
\hline t-value & (8.1558) & (7.5237) & (8.0065) & (8.3918) \\
\hline Scale & 0.5577 & -0.5131 & -0.0427 & 0.0925 \\
\hline Stderror & $(0.0321)$ & $(0.4915)$ & $(0.0844)$ & $(0.0651)$ \\
\hline \multicolumn{5}{|l|}{ 6. Textile: } \\
\hline $\ln Y$ & 1.4192 & 0.6480 & 0.3075 & 0.1844 \\
\hline t-value & (13.0667) & (6.3677) & (10.6672) & (7.0758) \\
\hline $\operatorname{lnPK}$ & 0.6321 & 0.4776 & 0.4013 & 0.2303 \\
\hline t-value & (17.1439) & (9.1138) & (8.3036) & (14.3001) \\
\hline $\operatorname{lnPW}$ & 1.6321 & 1.4776 & 1.4013 & 0.7697 \\
\hline t-value & (44.2654) & (28.1959) & (28.9938) & (47.8044) \\
\hline
\end{tabular}




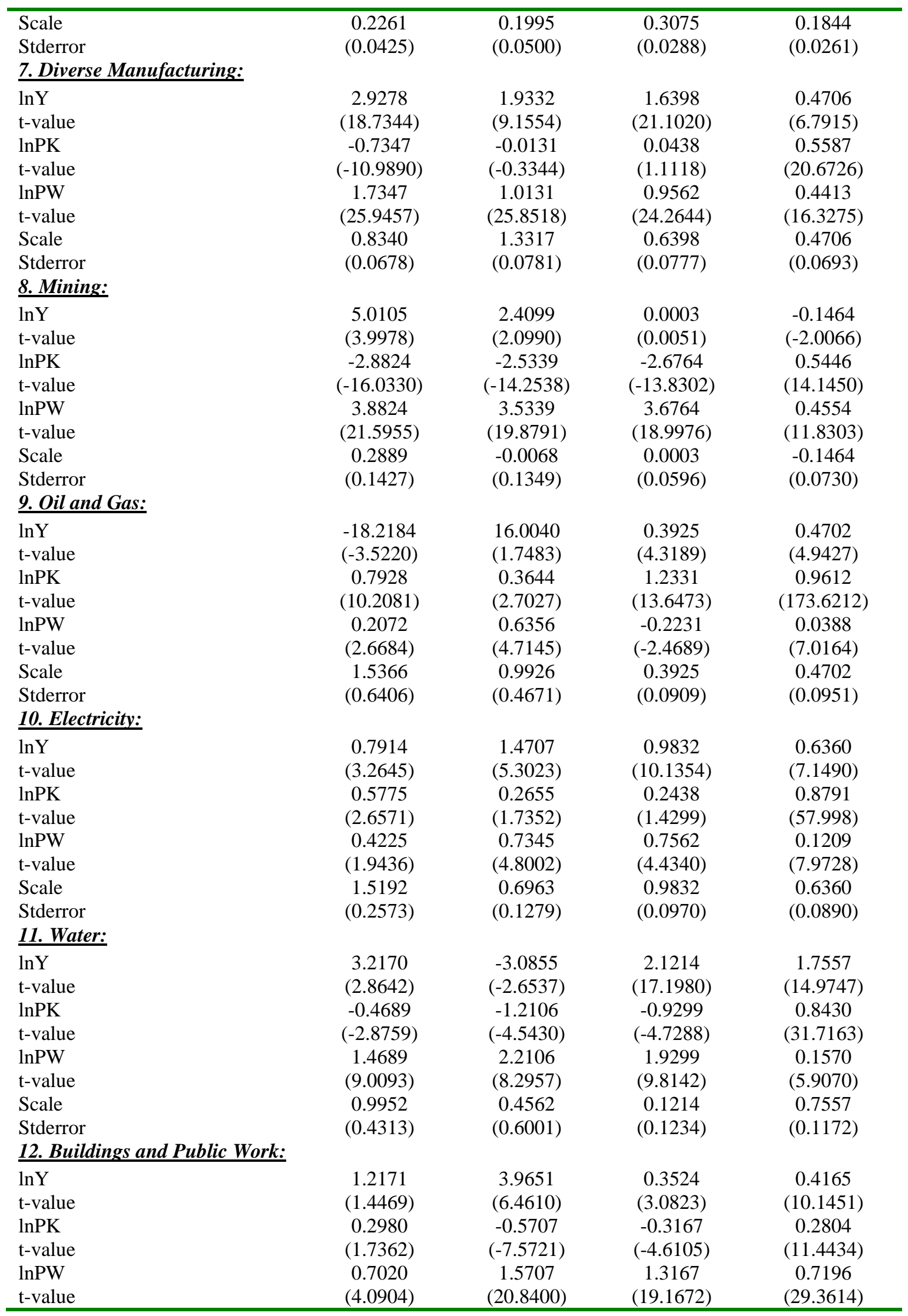




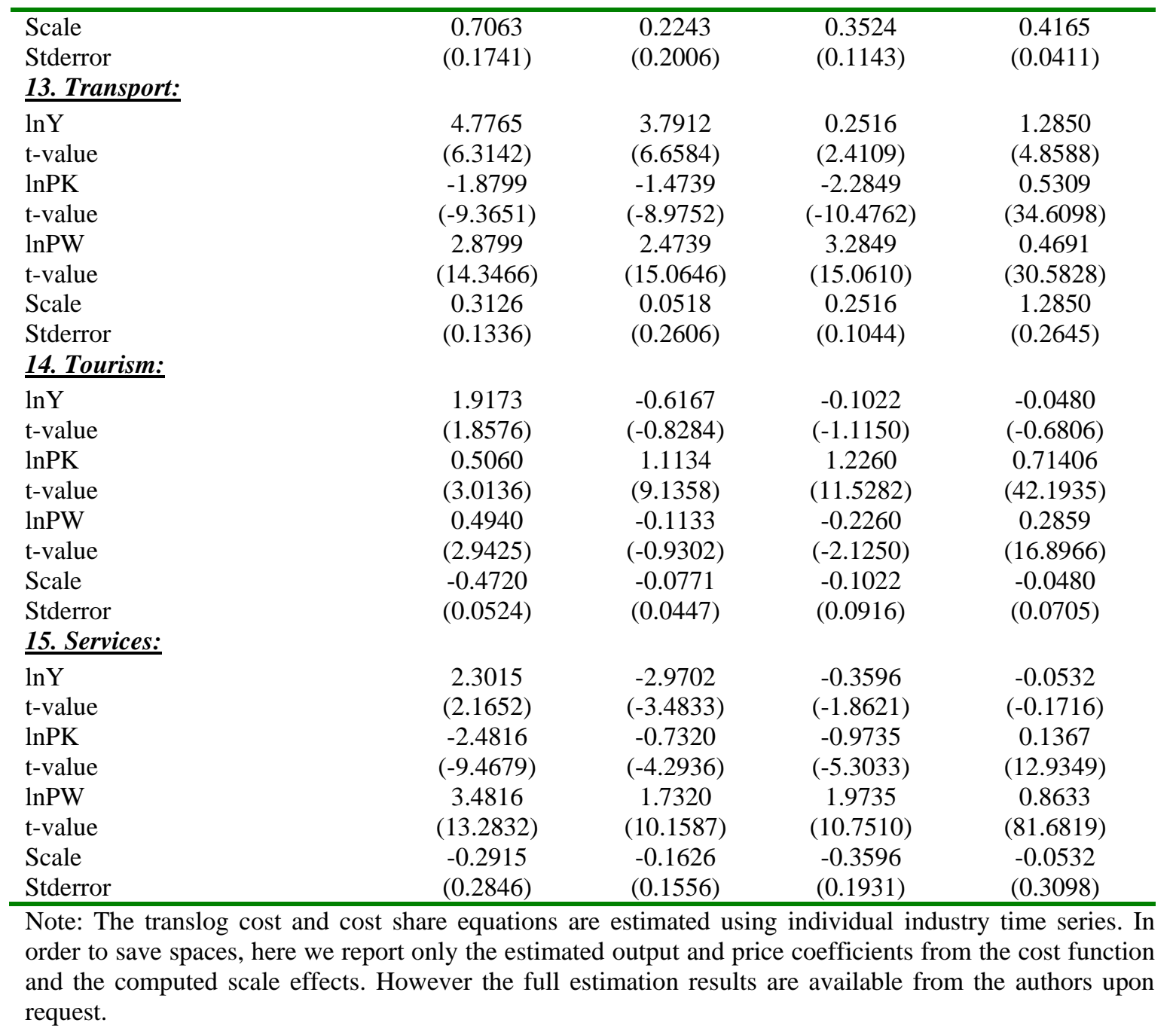

